Jesper Bremholm

\author{
Aarhus University \\ Charlotte Krog Skott \\ University College Capital
}

DOI: http://dx.doi.org/10.5617/adno.5540

\title{
Teacher planning in a learning outcome perspective: A multiple case study of mathematics and L1 Danish teachers
}

\begin{abstract}
Like most European countries, Danish education is facing a radical shift towards a focus on learning outcomes, which calls for renewed attention to teachers' instructional planning. In this article, we explore teacher planning in mathematics and L1 Danish, focussing particularly on the role of instructional materials. Using data from a lesson study project and a theoretical framework that conceptualises planning in a local institutional setting, we analyse planning at both teacher and school level. This allows us to identify practices in teachers' planning that may hinder an outcome perspective, but that nevertheless seem meaningful in a broader institutional context.
\end{abstract}

Keywords: Teacher planning, learning outcome, mathematics education, Danish as L1 education.

\section{Læreres planlægningspraksis i et læringsmålsperspektiv: Et multipelt casestudie af matematik- og dansklærere}

\section{Sammendrag}

Danmark står, som mange europæiske lande, over for radikale uddannelsesforandringer med lceringsmål som omdrejningspunkt, som krcever fornyet opmcerksomhed på lareres undervisningsplanlæegning. I artiklen udforsker vi lereres planlegningspraksis i matematik og dansk ved primcert at fokusere på den rolle, som undervisningsmaterialer spiller. Ud fra data fra et lektionsstudieprojekt og en teoretisk ramme, der begrebsliggør planlegning i en lokal institutionel kontekst, analyserer vi planlcegningspraksis ift. både et lcererog et skoleniveau. Dette gør det muligt at identificere praksisser, der forhindrer larere i at planlegge med fokus på lceringsmål, men som ikke desto mindre forekommer meningsfulde, når de forstås i en bredere institutionel kontekst 
Nøgleord: Læereres planlæegning, læeringsmål, matematikundervisning, danskundervisning (L1)

Since the beginning of the $21^{\text {st }}$ century, new European educational policies, in combination with the growth in international comparisons of students' achievements, have become increasingly important for the development of national educational policies (Haapakorpi \& Saarinen, 2014; Sivesind, Akker, \& Rosenmund, 2012). Antunes (2012) highlights the Bologna Process, the Copenhagen Process and the Education \& Training 2010 programme as three European policies that have led to what she terms paradigmatic change across European national educational systems at primary and lower secondary levels during the last decade. These radical changes have transformed education from a place for teaching, where the curriculum is content based, into a space for learning, where the focus shifts to predefined learning outcomes and competences (Antunes, 2012; Sivesind et al, 2012).

The increased focus on learning outcomes calls for a renewed focus on the importance of teachers' instructional planning (Antunes, 2012). Teachers are expected to translate general, abstract learning outcomes in policy documents into meaningful content and concrete, measurable outputs, and to decide on materials, activities and instructional approaches that align with this content and these outputs, as well as with a diverse student body and their various interests.

The radical educational changes at European level have strongly influenced the recent policy in Denmark, as well as a number of other European countries including Norway (Hodgson, Rønning, Skogvold, \& Tomlinson, 2010), Sweden and Portugal (Sivesind et al., 2012). In Denmark, the new national standards for primary and lower secondary schools (Undervisningsministeriet, 2016a, 2016b) consist entirely of different categories of learning outcomes, rather than specifying curricular content as previously. Each subject is divided into a few overall competence areas with broad learning outcomes, which, in turn, are divided into a number of more specific goals for knowledge and skills. As something new, the steering documents include direct and detailed instructions for teachers when planning their lessons. Hence, the documents encourage a four step sequence that approaches planning in a linear way (Undervisningsministeriet, 2014): 1) formulate concrete, observable and measurable outcomes based on the general learning outcomes found in the national standards, 2) select activities, that will support students in achieving these outcomes, 3) formulate observable indicators of student learning, and 4) choose appropriate assessment methods. In this sense, learning outcomes have become a general educational principle and tool at the macro level (Skott \& Kaas, 2015).

Despite a general agreement in educational research that planning lessons is a crucial component of teachers' professional competences (Ball \& Forzani, 2007; John, 2006; Norman, 2011; Warren, 2000), there is little empirical 
research on the topic (Hodgson et al., 2010; Warren, 2000). Furthermore, there are calls for empirical research into how the trends, challenges and effects of the new European educational policies influence teachers' practices (Antunes, 2012; Sivesind et al., 2012). The few empirical studies that investigate both instructional planning and the new educational trends stress that teachers face severe difficulties when trying to incorporate learning outcomes into their planning, especially in terms of formulating concrete and measurable outcomes based on the national standards (Hargreaves, Earl, Moore, \& Manning, 2001; Hodgson et al., 2010; Sullivan, Clarke, Clarke, Farrel, \& Gerrard, 2012).

In this article, we answer the call for more empirically based knowledge on teacher planning in general, and when applying a learning outcome approach in particular. We investigate the planning practices of Danish middle school teachers in mathematics and L1 Danish (hereafter Danish) with a dual aim. First, we identify potential barriers that might inhibit teacher planning with a learning outcome perspective. Second, we explore these barriers not only in relation to classroom practices (i.e. the micro level), but also from the perspective of the school as a local institutional setting (i.e. the meso level). Thus, we seek to answer the two questions:

1. Which barriers do middle school teachers in mathematics and Danish face when applying a learning outcome approach to their instructional planning?

2. How can these barriers and their interplay with other factors that influence teacher planning be understood from the perspective of the school as a local institutional setting?

\section{Empirical research on teacher planning}

In his review of empirical research on teacher planning, Warren (2000) points out that, prior to 1970, the research on teacher planning was exclusively theoretical and prescriptive in nature. It consisted primarily of guidelines outlining how educational planning should be carried out, as seen, for instance, in Tyler's (1950) influential Basic Principles of Curriculum and Instruction. Since the 1970s, empirically based studies of what teachers actually do when planning lessons have become established as a field of educational research. However, Warren's observation from 2000 that, empirical research on teacher planning is a relatively small field, is still valid today. This is also the case in a Nordic context where empirical research on teacher planning is rather limited in scope and has only recently emerged as an area of study (Hodgson et al., 2010).

We now present an overview of important findings from empirical studies on teacher planning. The structure of this overview is based on Warren's review and his classification of four main factors that influence and condition teachers' planning. It should be noted that the overview does not include studies related to 
planning within teacher education and training or intervention studies regarding specific planning programmes or procedures.

Teaching experience is the first factor exerting an influence on teachers' planning. Compared to newly qualified teachers, experienced teachers are more capable of, and are more focused on, establishing coherence between lesson activities, the curricular theme or unit plan that the lesson is part of and the general learning outcomes related to the subject in question (Aguirre, Haggerty, \& Linder, 1990; Aikenhead, 1984; Brown, 1988; Clark \& Yinger, 1987; Kagan \& Tippins, 1992; McCutchon, 1980). Likewise, they are more capable of establishing a coherent sequence of activities in a lesson and anticipating the students' probable responses to the activities (Stúkat, 1998). More recent studies confirm the importance of experience as a factor in teacher planning (Bachmann, 2005; Norman, 2011; Superfine, 2008). However, some of these studies also question whether the effect of experience is exclusively positive. Thus, in her study of the planning practices of three experienced mathematics teachers, Superfine (2008) points out that experience in the form of working routines and consolidated ideas about teaching can be an obstacle to a reflective and improvement-oriented practice.

The organisational framework in which instruction is situated is another factor influencing teachers' planning, especially aspects such as the school's timetable and allotment of time for different subjects (Aguirre et al., 1990; Brown, 1988; Duschl \& Wright, 1989; McCutchon, 1980; Nerland, 2006; Yinger, 1980). A couple of more recent Norwegian studies show that other organisational and contextual factors, such as teachers' working conditions, also have a considerable impact on their approach to planning. For instance, demanding workloads may induce teachers to lower their professional standards and seek pragmatic solutions (Carlgren \& Klette, 2008; Hodgson et al., 2010).

Instructional materials are a third important factor influencing teacher planning. Teachers use instructional materials as planning resources, both in relation to the choice of activities in a lesson and to the selection and sequencing of content in a unit plan (Bellon, Bellon, \& Blank, 1992; Boroko \& Niles, 1987; McCutchon, 1980; Sanchez \& Valcarcel, 1999; Sardo-Brown, 1990). The importance and impact of instructional materials is confirmed by several more recent studies (Haggarty \& Pepin, 2002; Ozturk, 2012; Sullivan et al., 2012; Superfine, 2008) and by studies specifically addressing a Nordic context (Alseth, 2004; Bachmann, 2005; Christophersen, 2004; Hodgson et al., 2010).

Attention to students' interests, needs and abilities is a fourth influential factor regarding teachers' planning. Studies show that teachers adjust the curricular content and level based on their knowledge and assessment of students' abilities, special interests and motivation (Brown, 1988; Clark \& Elmore, 1979; Duschl \& Wright, 1989). In a more recent study, Holmquist and Brante (2011) compare teachers in Sweden and Hong Kong with regard to their conceptions of planning. They observe that the Swedish teachers seem to be 
largely guided by their students' behaviour and interests when planning and describe this approach as "guiding for joy" and "guiding for peace". In contrast, the teachers in Hong Kong are guided primarily by their efforts to ensure that students learn the intended curricular content, which the authors characterise as "guiding for content-based learning" (p. 505).

As illustrated by this overview, empirical studies have provided valuable insight into a number of factors that influence teacher planning. However, the specific interplay between these factors in relation to teachers' actual planning practices is not directly addressed in these studies. This might be due to the fact that the predominant research method in this research is interviews. A small number of studies combine interviews with other research methods, such as Norman (2011), who also analyses planning documents and conducts observations. However, her study underpins the methodological bias of the interview, as pointed out by ten Have (2004): that there is no guarantee of consistency between what informants say that they do, and what they actually do.

Furthermore, none of the studies address teacher planning in a learning outcome perspective. Our study thereby contributes to the body of knowledge on teacher planning by examining the dynamics of the above mentioned interplay in order to better understand the barriers that teachers' planning practices might constitute with regard to a learning outcome perspective.

\section{A theoretical framework for examining teacher planning}

Inspired by Fairclough (2003), we theoretically conceptualise teacher planning as a social practice. Thus, we consider the relationship between social structures (i.e. institutional settings and conditions for teachers' work) and local events (i.e. a teacher plans a specific lesson) as mediated by the social practices of planning. The framework developed by McClain, Zhao, Visnovska and Bowen (2009) is based on a similar theoretical approach and conceptualises teachers' instructional practice in a local institutional setting by focusing on the interplay between their use of instructional materials and their instructional practice. The framework consists of three interrelated constructs encompassing different institutional levels and perspectives (see figure 1). We use the framework as an analytical tool to examine teacher planning. 


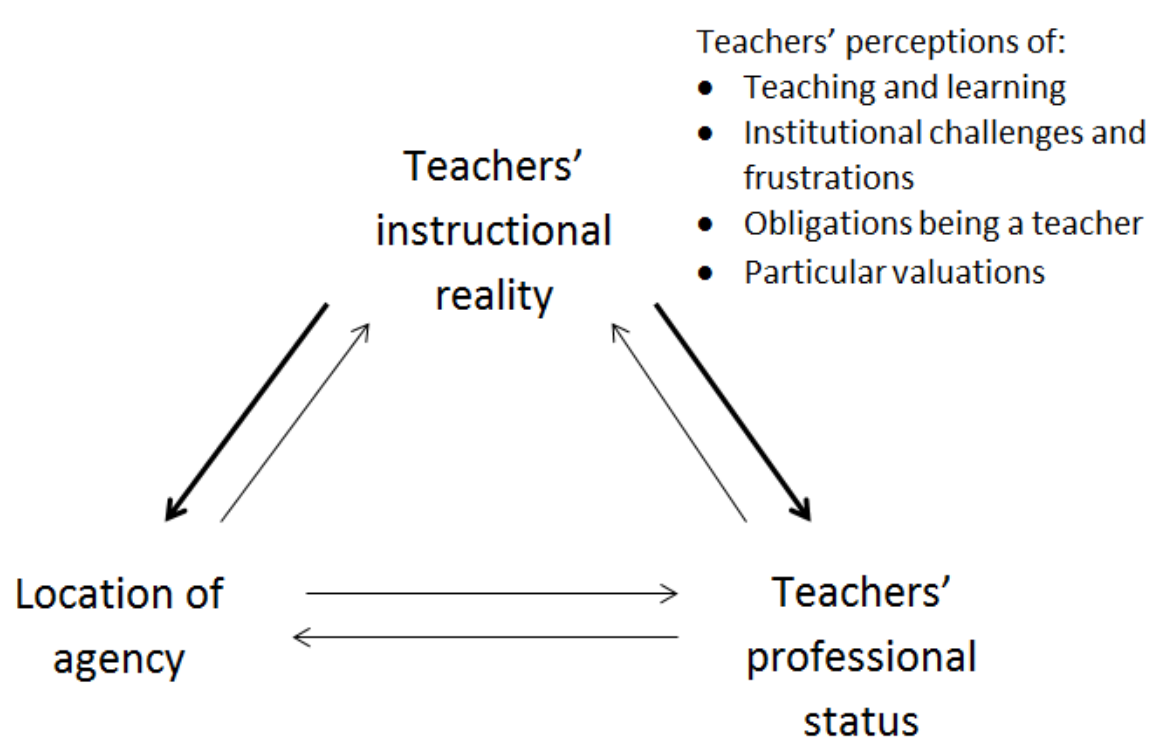

Figure 1: Constructions and relations influencing teachers’ planning (McClain et al., 2009).

The first construct, Teachers' instructional reality, refers to teachers' perspectives on planning and encompasses four factors that influence teachers' decision making: teachers' perceptions of 1) teaching and learning, 2) institutional challenges and frustrations, 3) obligations as a teacher, and 4) particular values. The construct is based on the assumption that planning is a complex and dynamic process that is profoundly influenced by the local institutional setting.

The second construct, Location of agency, is based on the assumption that what teachers do and how they justify their planning decisions is influenced significantly by the instructional materials and other available resources that they use. Agency is defined as "having authority over both the [subject $]^{1}$ that is taught and the sequencing and presentation of that content" (McClain et al., 2009, p. 63). Teachers' instructional reality is assumed to influence the location of agency to a greater extent than vice versa, as indicated by the arrows.

In contrast to these two constructs, Teachers' professional status refers to an outside perspective on teachers as professionals as represented by the school leadership, politicians and the general public. The assumption is that the degree to which teachers are regarded as professionals influences the two other constructs; for instance, shaping the teachers' view of their obligations as teachers. However, as indicated by the arrows in figure 1, teachers' actions, such as how they deal with institutional challenges, also have a considerable influence on how they are perceived professionally.

\footnotetext{
${ }^{1}$ The original version refers to mathematics.
} 


\section{A multiple case study}

We applied a multiple case study design with two cases to examine teacher planning in mathematics and Danish (Yin, 2003). The two cases replicate the same research design, which makes it possible to examine aspects specific to planning in one of the subjects as well as common aspects across the two subjects.

The empirical setting for our study was a year-long project implementing a lesson study approach in a municipal primary and lower secondary school in the Copenhagen area. Briefly put, lesson study is a collaborative approach intended to improve teaching in which teams of teachers systematically inquire into their own instruction following a procedure consisting of three consecutive collaborative processes (Murata, 2011). Lesson study is well suited to our research agenda as the first process consists of thoroughly planning both a unit and a so-called research lesson. Our two cases consist of the planning processes of two teams of $5^{\text {th }}$ grade teachers in mathematics and Danish respectively, each collaborating with two teacher educators from our research group. The participating teachers had no prior experience with lesson study. The mathematics team consisted of one male and two female teachers, all of whom had at least seven years of practical teaching experience. The Danish team consisted of three female teachers; two were relatively new to the profession and one had more than 30 years of experience. During three planning meetings, both teams produced a unit plan covering 10 lessons as well as a detailed lesson plan for the research lesson.

In the planning meetings, we (the authors) acted as participating observers with dual roles as facilitators and researchers (Yin, 2003). As facilitators, we participated in the discussions with the purpose of maintaining a focus on learning outcomes, and thus raising questions on outcomes and their connections to the specific content, activities and instructional approaches. As researchers, we gained access to the teachers' reflections and decision making processes through the collaborative deliberations in the meetings and hereby obtained indepth insights into an otherwise hard-to-access practice. Normally, teachers do not explicitly communicate such reflections or their mental planning strategies (Hodgson et al., 2010).

By using participatory observation, we tried to avoid the methodological bias related to interviews regarding the possible discrepancy between what an informant says and does. However, by assuming the role of participants, we introduced another element of bias, inasmuch as it meant that we did not observe the teachers in a typical planning situation, as well as by influencing the teachers' reflections and decision making. We responded to this bias by designing our study as critical cases (Flyvbjerg, 2010). Our cases are critical in the sense that the lesson study project created almost ideal conditions for the teachers' planning by providing extra time, a collaborative setting and external 
support. We therefore assume that the barriers we identify in these two critical cases their are also likely to influence teachers under less favourable conditions and to impede planning with a learning outcome perspective.

We collected the following data (audiotaped and transcribed):

- Six individual, semi-structured interviews with teachers before the lesson study. Our purpose was to get insights into the individual teacher's planning practices and teaching values.

- Three two-hour planning meetings with each of the two teams collaborating with our research group.

In order to answer our research questions, we conducted a two-step analysis. In the first step, we analysed the teachers' decision making as regards their use of instructional materials by using teachers' location of agency as our analytical optic. The aim of this step was to identify barriers that seemed to prevent each team of teachers from planning with a learning outcome perspective at the micro level. Hence, we focused on the ways in which the teachers argued for their planning decisions and the interplay between these decisions and their instructional materials. In the second step, we compared and combined the two cases in order to arrive at a broader understanding of these barriers as seen from the meso level by using teachers' instructional reality as our analytical lens. In this analysis, we looked at how the teachers articulated their perceptions of being a teacher in today's school with regard to teaching and learning, institutional challenges and frustrations, the obligations as a teacher and particular values related to teaching (cf. Figure 1) The macro level is not included in the analysis, primarily because we did not have access to the necessary data from the school leadership and beyond the institution to conduct this kind of analysis. As a consequence, the teachers' professional status (cf. Figure 1) is not applied as an analytical category.

\section{The two cases - analysis and findings}

We now present our two-step analysis of the two cases in mathematics and Danish. As described above, the cases will be analysed separately in the first step before being compared and combined, with the support of additional data extracts, in the second step.

\section{Identifying barriers in the teachers' planning}

\section{Case 1: Teacher planning in mathematics}

The mathematics teachers chose volume as the topic for the upcoming unit plan (a block of 10 lessons) as this was the topic of the next chapter in the textbook used by all three teachers. In this chapter, the formula for calculating the volume 
of a box was presented, followed by a number of training tasks. In the case, we identify a conflict concerning the teachers' location of their agency. Initially, the teachers wanted to assume a high degree of agency. However, especially when making concrete decisions, they tended to stick tightly to their instructional materials both when deciding on concrete learning outcomes and when selecting and sequencing the content. We use the term relinquish to characterise the teachers' surrender of agency as, in principle, they had the opportunity to assume much more agency in the situation.

In the first planning meeting, the teachers questioned the instructional approach to volume found in the textbook. As one teacher said, referring to the guide for teachers: "Volume is not only about [filling boxes with] centicubes". Their search for an alternative approach was also reflected in their contributions to an initial discussion of appropriate learning outcomes for the unit, such as: "I think there should be some outcomes related to problem solving". However, in this discussion of outcomes, the teachers tended to confuse outcomes with other goals and purposes. For instance, they would highlight the goal of strengthening students' practical experience: "Students need to have (...) concrete experiences with the weight of an orange", or they would address students' motivation: "Students like the kind of competition you get in activities such as 'Draw a line that accurately measures one metre'”. The teachers expressed their suggestions for 'outcomes' in brief terms without supplementary reflections, but also without reference to instructional materials. Despite the teachers' engagement in this discussion of outcomes, they constantly initiated alternative lines of discussion on topics such as student motivation, teaching activities and the use of digital technologies: "It would be great if the students had that program (...) it is quick to do on the computer". Nevertheless, the teachers, with our support, succeeded in formulating two specific outcomes in the first part of the meeting, namely that the students: 1) understand volume as a mathematical concept, 2) can derive a formula for the volume of boxes. These outcomes underpin a problem-solving approach to volume and were agreed upon by the teachers: "If you do not understand the concept of volume, it [using the formula] will be rote learning".

However, by the end of the meeting, one of the teachers had copied two general outcomes from the national standards into the unit plan instead of the two specific outcomes they had developed: "The students can estimate and calculate volumes", and "The students know about geometrical drawing methods to represent spatial figures" (Undervisningsministeriet, 2009). These outcomes were detached from the previous discussions and decisions. They blurred the choice of content and did not directly support a problem-solving approach. Though encouraged to reflect upon and make these abstract outcomes more specific and applicable - or to return to the previous ones - the teachers stuck to them without further pedagogical or content-related argumentation. Hence, the teachers and we as facilitators did not succeed in establishing 
sufficiently specific and concrete outcomes that could inform and guide our planning. The frequent lack of substantive pedagogical and mathematical argumentation complicated our decision making and resulted in a unit plan without coherence between outcomes, activities and instructional approach.

In interviews, the teachers stated that they normally relied strongly on the textbook in their lesson planning: "I consider the textbook material to be so good that it ensures that I will touch upon the national standards as I am required to". However, as pointed out above, the teachers initially signaled their desire to assume more agency than normal and advocated for a problem-solving approach that did not rely directly on the instructional materials, and they formulated outcomes in accordance with this approach. In this light, the teachers' decision to replace the specific outcomes with the national standards is surprising. This sudden shift in the teachers' location of agency, moving away from their own professional judgement towards the national standards when making concrete decisions, was a central turning point in the planning process. The case highlights factors connected to this shift: the teachers' inexperience with formulating concrete learning outcomes, their confusion about what defines an outcome, and their conception of outcomes as external in relation to the content and quality of planning.

The resulting unit plan was divided into five sub-themes:

1. Introduction of the concept of volume

2. Students derive the formula for the volume of boxes

3. Training students' use of the formula

4. Isometric drawing

5. Assessment of the students' understanding of volume and the formula.

The second of these sub-themes was chosen as the focus for the research lesson. All the other sub-themes, and their sequencing, were identical to the textbook chapter on volume. However, even the second sub-theme fits easily into the teachers' normal use of the textbook, as it is merely an introductory supplement. During the planning meetings, the teachers were strongly encouraged to reflect and argue pedagogically and mathematically for these choices of content and sequencing, and to make adjustments. However, as the unit plan illustrates, the teachers stuck closely to the decisions in the textbook and, thus, located the agency there.

Summing up, the case illustrates the teachers' relinquishment of agency to the national standards and the textbook as regards outcomes, choice of content and its sequence when planning with a learning outcome perspective despite being in an unusual planning situation with rich opportunities to hold more agency and showing an initial desire to do so. The case offers insight into how this relinquishment of agency constitutes a barrier to plan with a learning 
outcome perspective by preventing teachers from, reflecting as professionals on outcomes, pedagogical and mathematical matters and their connections.

\section{Case 2: Teacher planning in Danish}

The team of Danish teachers carried the planning out in connection with an interdisciplinary course (between Danish and History) with the Second World War as a common topic. We will argue that the case shows how the Danish teachers' use of instructional materials is characterised by what we term quick decisions. This indicates that the teachers' approach to instructional materials is directed by a logic of efficiency that, on the one hand, shows that the teachers have full agency regarding the choice of materials, but, on the other hand, does not combine well with reflections on planning and learning outcomes. We present three episodes from the three planning meetings: two episodes that illustrate a quick decision and one where the logic of the quick decision is suspended. Most of the first meeting was devoted to a discussion of the unit plan that the teachers had drafted prior to the meeting. This draft consisted partly of a list of texts and other instructional materials proposed by the teachers, and partly of a number of learning outcomes cited from the national standards. Both fiction (novels and poetry) and non-fiction (articles and extracts from The Diary of Anne Frank) texts were included. The discussion of the unit plan led to our formulation of the following overall outcome for the unit: "The students should experience the Second World War as represented in different genres". As such, this represents a teaching goal more than a learning outcome.

In the rest of the meeting, we addressed the question of selecting an appropriate text for the research lesson. The choice of text was the result of a quick decision. One teacher proposed an expository text about the German persecution of the Jews in Holland during the $\operatorname{war}^{2}$ (an article from the teachers' list) supported by the argument that "it is a really good text for teaching the students about expository texts". The two other teachers agreed and, without further discussion, the choice was made.

When we read the text as part of our preparation for the second meeting, we were sceptical as to whether it was an appropriate text for $5^{\text {th }}$ grade students in relation to the above-mentioned outcome. In our view, the text had some very problematic aspects - lexically (too difficult), with regard to its genre (blurred), and its ethics (the way it portrayed the persecution of the Jews). Thus, we decided that we would address this choice of text at the meeting if the teachers did not bring it up themselves, which they did not. When we raised the question, it turned out that none of the teachers had actually read the text prior to choosing it, including the teacher who had suggested it. As she put it: "it was somewhat random that I picked that text out. It wasn't very deliberate”. The renewed

\footnotetext{
${ }^{2}$ Larsdottor, A. (2008). The diary of Anne Frank tells us about the terror of the Nazis (our translation. The original title is Anne Franks dagbog fortæller om nazisternes terror).
} 
discussion resulted in a decision to choose another text. This lead to another animated discussion and in the end, the teachers suggested using an excerpt from The Diary of Anne Frank that featured on their list. As in the first meeting, they were inclined to make a quick decision without having read the text, but only a short description of it in the teacher guide. This is illustrated by a short exchange:

Teacher 1: The teacher guide says that the third excerpt shows us Anne's thoughts about the serious events outside their hiding place, and that it testifies to her maturity and profundity. We could choose this.

Teacher 2 and 3 (simultaneously): Mmm, good idea.

We suggested that we read the excerpts before making a choice. The teachers concurred, and the decision was postponed until the third meeting.

At the beginning of this meeting, two of the teachers declared that they had not read the excerpts. The third teacher had read it, but only due to extraordinary circumstances: She had been forced to stay home the preceding day because her child was ill, and this had allowed her time to read the excerpts thoroughly. This situation strongly influenced the meeting and led to the suspension of the quick decision as to how to approach the instructional materials. Instead, the third teacher initiated a substantive and detailed discussion about the educational pros and cons of the different excerpts, which took up a considerable part of the meeting.

This discussion led to the conclusion that one of the excerpts was particularly well-suited for the research lesson because it was a particularly clear example of how Anne Frank, through the literary style of the diary, depicts the experience of the war as seen through the eyes of a child (cf. the outcome). Consequently, this excerpt was chosen for the research lesson.

To sum up, while the case shows that the Danish teachers have full agency regarding the choice of instructional materials, they keep practising the quick decision in their approach to instructional materials and only suspend this practice in extraordinary circumstances - the question is why? A similar question regards the mathematics teachers' practice of relinquishing agency to the instructional materials. Both of these practices constituted important barriers preventing the teachers from planning with a focus on learning outcomes. We address both questions in our second analytical step with the purpose of understanding these barriers in a broader perspective related to the school as an institutional context for the teachers' practice.

\section{Barriers to planning in light of teachers' instructional reality}

We use teachers' instructional reality as a concept for analysing the two aforementioned barriers in order to reach an understanding that goes beyond the classroom level. As described earlier, the teachers' instructional reality is composed of their perceptions of four different aspects: teaching and learning, 
institutional challenges, obligations as a teacher, and particular values. Our analysis is structured accordingly and focuses on both similarities and differences between the two groups of mathematics and Danish teachers.

\section{Teachers' perceptions of teaching and learning: High levels of confidence in instructional materials and in teaching experience}

To a large extent, the mathematics teachers consider the textbook to be a guarantee of well-founded teaching, while the Danish teachers express a similar conviction regarding teaching experience.

In the first case, we argued that a shift occurred in the mathematics teachers' location of agency from relying primarily on their own professional judgement to relinquishing the agency to the national standards when it came to concrete decision making. We interpret this shift as partly related to the teachers' lack of familiarity with learning outcomes. In particular, the case showed both that the teachers relinquished their agency in this unusual planning situation, and that they did so in relation to the choice of content, its sequence as well as the learning outcomes. However, taking into account the authority that mathematics teachers generally assign to instructional materials, including national standards (Bachmann, 2005; Haggarty \& Pepin, 2002; Superfine, 2008), it appears quite logical that the teachers relinquished the agency to these materials with regard to identifying learning outcomes, even when these are too abstract and complex to use as planning tools.

The Danish teachers do not endow the instructional materials with the same authority, perhaps because they do not rely on a single (or few) textbook but use a selection of different materials. One possible explanation for this difference is the ontological difference between mathematics and Danish as subjects, in the sense that Danish includes more diverse content areas than mathematics (Nielsen, 2004). Consequently, Danish is harder to represent in a single textbook than mathematics.

The Danish teachers particularly accentuated teaching experience as a prerequisite for good teaching and as pivotal for the ability to make adequate pedagogical decisions in a given situation. As explained by the most experienced teacher:

Most of the time, I don't make detailed written plans. Early on as a teacher, I discovered that plans made me more restrained and stressed. Now, I mostly sense the atmosphere when I step into the classroom to know which direction we are going today. I always know where I am heading, but I am also ready to make adjustments along the way. Making adjustments is complicated, but it gets easier with experience.

This strong emphasis on experience might support an idea of teaching that downplays the importance of planning, since the quality of teaching is seen as primarily dependent on the teacher's situated decision making. In this light, the quick decision appears to be a rational planning practice inasmuch as the 
importance of the teacher's performance in the classroom renders the choice of specific instructional materials less significant.

\section{Teachers' perceptions of institutional challenges and their frustrations: working conditions as legitimising logic}

The two teams have similar views on their working conditions and the institutional context surrounding their profession. They describe their everyday life as teachers as characterised by a heavy workload resulting from many lessons each day in different classes and subjects ${ }^{3}$, as well as a number of other tasks to be dealt with within a highly limited time frame (meetings, administrative tasks, various practicalities, issues and conflicts with students, dialogue with parents etc.). A mathematics teacher points to the increased workload resulting from documentation requirements: "We need to make a yearplan as documentation for the parents (...) But hardly any parents read them". One Danish teacher explicitly links working conditions and planning:

There is less and less time for collaboration and planning. Simply because of stress, and the fact that we have too much work. Many now have two Danish classes; before, they only had one. This makes it almost impossible to collaborate and plan.

The teachers have limited and, in their own opinion, insufficient time for planning, which in turn necessitates a high degree of efficiency as they need to plan multiple lessons each day in a short time. These working conditions, and in particular the demand for high efficiency, might legitimise a superficial approach to planning in the sense that teaching without or with only minimal planning becomes the accepted norm. Both the mathematics teachers' relinquishing of agency and the Danish teacher's quick decision might be seen as manifestations of this norm and its underlying legitimising logic.

\section{Teachers' perceptions of the obligations as a teacher: A tendency towards an instrumental approach to the national standards}

Both teams describe the obligations of a teacher as a question of meeting and balancing a diverse array of demands that together constitute the complex reality of the profession: classroom management, inclusion of a very diverse student body, assessment, use of ICT and, last but not least, the national standards. The teachers are conscious of their obligation to base their teaching on designated learning outcomes, but the obligation is perceived more as an external demand to be remembered than as a meaningful pedagogical tool to qualify their teaching. One of the mathematics teacher expresses this separation of outcomes and content by emphasising outcomes as something primarily to be remembered: "We need to remember those outcomes. I think many of us are very bad at remembering them". One of the Danish teachers is very explicit

\footnotetext{
${ }^{3}$ In primary and lower secondary schools in Denmark, the teachers’ usually teach in several different subjects.
} 
about the conflict she faces between the obligation to base her planning on the national standards and the meaningful use of the standards as a planning tool:

I know I am obliged to make an overall course plan for the year, and I do it. But I think it's really difficult with the national standards (...) In the course plan, I write down all those learning outcomes, but in my detailed planning I don't use them at all.

These quotes also illustrate that the teachers show a strong tendency to practise an instrumental approach to the national standards, which contradicts the basic principle behind the steering documents on learning outcomes.

The instrumental approach manifests itself differently in the two subjects. For the mathematics teachers, the instrumental approach to the national standards is partly a consequence of the fact that they assign a great deal of authority to the instructional materials with regard to outcomes, content and sequencing, and partly a result of their lack of experience with reflections on and practices associated with a learning outcome perspective. In this regard, the case points to a potential vicious circle as the teachers' unfamiliarity with an outcome perspective might lead to a greater relinquishment of their agency to the instructional materials. In this way the teachers become even more dependent on these materials as the task of assuring coherence between outcomes and activities is displaced from the teachers' domain of responsibility to these materials and is therefore no longer a matter for reflection for the teachers.

For the Danish teachers, the national standards are an inventory of curricular content instead of the intended purpose of determining learning outcomes. In the interviews and planning meetings, we observe how the Danish teachers tend to use the standards as a checklist when selecting teaching content, as seen in the case when the teachers want to work with expository texts. They use the standards to verify if this is a suitable choice of content for $5^{\text {th }}$ grade, but do not reflect on the appropriateness of the instructional material in terms of achieving the desired learning outcomes.

In both cases, the teachers' planning practices seem a logical result of their instrumental approach to the national standards. Since the mathematics teachers consider the textbook authoritative regarding the standards, it logically permits them to relinquish agency to the textbook. Similarly, the Danish teachers' use of the standards as an inventory for teaching content, instead of as guidelines for reflecting on learning outcomes, allows them to make quick decisions when planning.

\section{Teachers' particular values in teaching: The pedagogical values override the subject-related values}

Both teams express professional values that may be characterised as general pedagogical values rather than subject-related values. Even though, in the interviews, the teachers profess to embrace a variety of different values in their 
teaching, they all emphasise general pedagogical values such as a positive learning environment, high levels of student activity, the inclusion of all students and the use of ICT. This prioritisation is illustrated by one of the Danish teacher's characterisation of her own teaching "It is important that the students are active. If I sense that it is too boring, and they are getting restless or tired, I change the activity". However, there is also a clear difference between the two teams regarding their attention to subject-related values understood as the positive appraisal of subject-specific competences or knowledge domains When asked what they consider important in their teaching, the Danish teachers do not mention any subject-related values, whereas the mathematics teachers stress the importance of developing students' mathematical competences: "What I wanted to achieve with those tasks was to make the students start to think mathematically and develop some of the competences, such as reasoning and problem solving”. In spite of this, the mathematics teachers generally also place greater emphasis upon general pedagogical values than subject-related ones. Again, the two planning strategies seem understandable in light of the values the teachers prioritise. Both the mathematics teachers' relinquishment of agency and the Danish teachers' quick decisions regard subject-specific aspects of their decision making when planning, and since the teachers are primarily preoccupied with general pedagogical issues, they can apply these planning strategies without violating their main professional values.

\section{Discussion}

Our two-step analysis suggests that the planning practices that we identified as barriers to a learning outcome perspective at the micro level appear to be meaningful and logical strategies when understood in a broader institutional context at the meso level, through the lens of the teachers' instructional reality. In order to nuance, challenge and substantiate these findings, we will compare with other relevant research findings.

On the one hand, our study confirms existing research regarding the importance of instructional materials and experience in teacher planning. On the other, the study also complements this research by showing how teachers' reliance upon instructional materials and experience can impede a planning practice directed towards learning outcomes. In this regard, our study corroborates the findings of Bjuland, Helgevold and Mynthe (2015). In their study, focused on student teachers during internships, they show how Norwegian teachers' (increasing) dependence on instructional materials prevents student teachers' from engaging in in-depth professional reflections on teaching, planning and learning during their internship. Our study also concurs with the findings in the study by Superfine (2008) with regard to teacher experience and reflective practice, since both studies show that teaching experience does not 
necessarily lead to a reflective and developmental approach to planning and teaching.

Our analysis supports research showing that demanding working conditions might impair teachers' planning practices (Carlgren \& Klette, 2008; Hodgson et al., 2010; Nerland, 2006). However, our analysis also adds nuance to these findings by indicating that time constraints and high demands for work efficiency might not only have a negative effect on the teachers' priorities regarding the time and effort they invest in the planning process, but also on their perceptions of what is an acceptable professional approach to teaching and planning. One could argue that the second effect is the more serious of the two inasmuch as it regards the essentials of their professionalism as teachers, and if this professionalism is undermined, it is not easily re-established.

The teachers in our study tend to use the national standards instrumentally, which goes against the intentions of the learning outcome paradigm. However, this tendency aligns with Bachmann's (2005) investigation of factors that influence teachers' implementation of a new national curriculum that places a strong emphasis on learning outcomes. It appears from the quote below that the teachers in Bachmann's study relinquish agency to the materials in much the same way as the mathematics teachers in our study:

The teachers consider the instructional materials as valid groundwork for their pedagogical decision making inasmuch as the instructional materials reconstruct the outcomes and content of the national curriculum in (what they expect to be) an adequate manner [ ... ]. This means that the instructional materials have a legitimising function with regard to the teachers' professional decisions (2005, p. 345, our translation).

Our analysis shows that the teachers are primarily preoccupied with general pedagogical and behavioural issues when planning lessons. This aspect of the analysis adds nuance to the existing research about teachers' attention to students' interests, needs and abilities as an important factor in planning by showing that over-emphasising general pedagogical and behavioural issues might prevent planning practices oriented towards learning outcomes. In this sense, the teachers in our study resemble the Swedish teachers in the aforementioned comparative study by Holmquist and Brante (2011) on teachers based in Sweden and Hong Kong. The Swedish teachers were primarily focused on the students' well-being and interests, while the Hong Kong-based teachers were focused on curricular content and student learning. Fauskanger (2016) points out a similar tendency in Norway in her study of teachers' descriptions of what characterises good mathematics teaching. All the teachers in Fauskanger's study stressed encouraging student engagement and activity as key pedagogical values. 


\section{Concluding remarks}

We have shown how empirical inquiry into teachers' planning practices enable the identification of barriers with regard to the implementation of a learning outcome approach. We have been able to show how a number of factors detailed by previous research (such as teaching experience, organisational frameworks, instructional materials and attention to the students' interests, needs and abilities) and other factors (see below) enter into a complex interplay that conditions and shapes planning among the teachers in our study. Despite the limited scope of our study, based as it is on two cases, we maintain that is has produced important insights into teacher planning. Thus, our study indicates that the particularities of the teachers' practices and the barriers they constitute in regard to a learning outcome perspective might be understood as a consequence of a complex interplay between factors such as the teachers' trust in instructional materials, their faith in professional experience, working conditions that legitimise a superficial approach to planning, their instrumental use of the national standards and their prioritisation of general pedagogical values.

McClain et al. (2009) argue that qualifying teachers' use of instructional materials is a matter of supporting and securing their agency: "The work of professional development is to support the teachers' movement of agency away from curriculum materials to a local view in which they hold the agency" (p. 64). However, our study indicates that this solution is an over-simplification. Generally, teachers in Denmark have extensive autonomy in terms of their professional practices (i.e. high professional status); as such, at least in principle, they have full agency concerning their choice and use of instructional materials. Nevertheless, the teachers in our study demonstrate a use of materials characterised by a limited degree of professional reflection both with regard to subject matter content and pedagogical decision making This finding indicates that, if the objective is to develop and qualify teachers' planning practices, it seems necessary to address the complexities that determine these practices. There does not seem to be a quick and a simple one-size-fits-all solution.

Our study suggests that a focus on learning outcomes requires quite radical changes to teachers' planning practices. Considering the current tendencies in educational policy in Denmark - and, it would seem, in the other Nordic countries - the teachers in our study seem to be faced with an almost impossible task. On the one hand, they must adapt their planning practices in order to live up to new requirements concerning learning outcomes. On the other, the conditions that could support such changes do not seem to be in place. In-service training methods, such as lesson studies, might constitute a first step towards a qualification and professionalization of teacher planning. However, due to the complexity of possible factors at play, such methods cannot stand alone. Our study suggests that an effort is needed which not only considers teachers' opportunities at the micro level to assume a higher degree of agency, but also 
stresses the importance of the right conditions at the meso and macro levels to support teacher professionalism. In other words, a long-term and multifaceted effort is necessary as many aspects of teachers' instructional reality must change if teachers are to fully incorporate a learning outcome approach in their planning.

\section{About the authors}

Jesper Bremholm is associate professor in literacy and Danish as L1 at Aarhus University. His main research interests are domain-specific literacy and teacher competences regarding the teaching of literacy.

Institutional Affiliation: The Danish School of Education (DPU), Aarhus University,

Tuborgvej 164, 2400 Copenhagen, Denmark

E-mail: jolm@edu.au.dk

Charlotte Krog Skott is associate professor in mathematics education at University College Copenhagen. Her research interests include teachers' professional development, especially in relation to lesson study, and use of digital technologies.

Institutional Affiliation: The Faculty of Teacher Education, University College Copenhagen, Humletorvet 3, 1799 Copenhagen, Denmark

E-mail: cksk@kp.dk

\section{References}

Aguirre, J.M., Haggerty, S.M., \& Linder, C.J. (1990). Student-teacher conceptions of science, teaching and learning: a case study in pre-service science education. International Journal of Science Education, 12, 381-390. https://doi.org/10.1080/0950069900120405

Aikenhead, G.S. (1984). Teacher decision making: The case of Prairie High. Journal of Science Teaching, 21, 167-186. https://doi.org/10.1002/tea.3660210208

Alseth, B. (2004). Endret læreplan = endret matematikundervisning? In K. Klette (Ed.), Fag og arbeidsmåter i endring? Tidsbilder fra norsk grunnskole (pp. 38-54). Oslo: Universitetsforlaget.

Antunes, F. (2012). 'Tuning' education for the market in Europe? Qualifications, competences and learning outcomes: Reform and action on the shop floor. European Educational Research Journal, 11(3), 446-470. https://doi.org/10.2304/eerj.2012.11.3.446

Bachmann, K.E. (2005). Lcreplanens differens: Formidling af læereplanen til skolepraksis. Ph.d.-dissertation, Trondheim: Norges teknisk-naturvitenskapelige universitet. 
Ball, D. L., \& Forzani, F. M. (2007). What makes education research "educational"? Educational Researcher, 36(9), 529-540. https://doi.org/10.3102/0013189X07312896

Bellon, J.J., Bellon, E.C., \& Blank, M.A. (1992). Teaching from a research knowledge base: A development and renewal process. New York: Macmillan.

Bjuland, R., Helgevold, N., \& Munthe, E. (2015). Lesson study og lærerstudenters fokus på eleveres læring i veiledningssamtaler. Acta Didactica Norge, 9(1), no.3. https://doi.org/10.5617/adno.1299

Boroko, H., \& Niles, J. (1987). Descriptions of teacher planning: Ideas for teachers and researchers. In V. Koehler (Ed.), Educators' Handbook: Research into Practice (p. 167187). New York: Longman.

Brown, D. (1988). Twelve middle school teachers' planning. Elementary School Journal, 89, 69-87. https://doi.org/10.1086/461563

Carlgren, I., \& Klette, K. (2008). Reconstructions of Nordic teachers: Reform policies and teachers' work during the 1990s. Scandinavian Journal of Educational Research, 52(2), 117-133. https://doi.org/10.1080/00313830801915754

Christophersen, J. (2004). Empirisk samfunnsfag eller lærebokfag: Lærebokas betydning i samfunnsfaget i forhold til læreplan, andre læremidler og informasjonskilder. In K. Klette (Ed.), Fag og arbeidsmåter i endring? Tidsbilder fra norsk grunnskole (pp. 101-117). Oslo: Universitetsforlaget.

Clark, C., \& Elmore, J. (1979). Teachers' planning in the first weeks of school (Research Series No. 56). East Lansing: Michigan State University.

Clark, C., \& Yinger, R. (1987). Teacher planning. In D. Berliner \& B. Rosenshine (Eds.), Talks to teachers (pp. 342-365). New York: Random House.

Duschl, R.A., \& Wright, E. (1989). A case study of high school teachers' decision making models for planning and teaching science. Journal of Research in Science Teaching, 26, 467-501. https://doi.org/10.1002/tea.3660260602

Fairclough, N. (2003). Analysing discourse: Textual analysis for social research. New York: Routledge.

Fauskanger, J. (2016). Matematikklæreres oppfatninger om ingrediensene i god matematikkundervisning. Acta Didactica Norge, 10(3), no.5. http://dx.doi.org/10.5617/adno.2560

Flyvbjerg, B. (2010). Fem misforståelser om casestudiet. In S. Brinkmann \& L. Tanggaard (Eds.), Kvalitative metoder: En grundbog (pp. 463-488). København: Hans Reitzels Forlag.

Haapakorpi, A., \& Saarinen, T. (2014). Transnationalisation and Nordic higher education. Nordic Studies in Education, 3(4), 149-152.

Haggarty, L., \& Pepin, B. (2002). An investigation of mathematics textbooks in England, France and Germany: Some challenges for England. Research in Mathematics Education, 4, 567-590. https://doi.org/10.1080/14794800008520106

Hargreaves, A., Earl, L., Moore, S., \& Manning, S. (2001). Learning to change: Teaching beyond subjects and standards. San Francisco: Jossey-Bass.

Hodgson, J., Rønning, W., Skogvold, A. S., \& Tomlinson, P. (2010). På vei fra lcereplan til klasserom: Om lereres fortolkning, planlegging og syn paa LK06. Report, Bodø: Nordland Research Institute. 
Holmquist, M., \& Brante, E. W. (2011). What is discerned in teachers' expressions about planning? Similarities and differences between teachers from Sweden and Hong Kong. Education Inquiry, 2, 497-514. https://doi.org/10.3402/edui.v2i3.21996

John, P. D. (2006). Lesson planning and the student teacher: re-thinking the dominant model. Journal of Curriculum Studies, 38, 483-498. https://doi.org/10.1080/00220270500363620

Kagan, D.M., \& Tippins, D.J. (1992). The evolution of functional lesson plans among twelve elementary and secondary student teachers. Elementary School Journal, 92, 477-489. https://doi.org/10.1086/461703

McClain, K., Zhao, Q., Visnovska, J., \& Bowen, E. (2009). Understanding the role of the institutional context in the relationship between teachers and text. In J. Remillard, B. A. Herbel-Eisenmann, \& G. M. Lloyd (Eds.), Mathematics teachers at work (pp. 56 - 69). London: Routledge.

McCutcheon, G. (1980). How do elementary school teachers plan? The nature of planning and influences on it. Elementary School Journal, 81, 4-23. https://doi.org/10.1086/461201

Murata, A. (2011). Introduction: Conceptual overview of lesson study. In L. C. Hart, A. S. Alston, \& A. Murata (Eds.), Lesson Study Research and Practice in Mathematics Education (pp. 1-12). Amsterdam: Springer.

Nerland, M. (2006). Vilkår for reflektert praksis i utdanningsinstitusjoner. Nordisk Pedagogik, 26, 48-60.

Nielsen, F.V. (2004). Fagdidaktikkens kernefaglighed. In K. Schnack (Ed.), Didaktik på kryds og tværs (pp. 25-46). København: Danmarks Pædagogiske Universitets Forlag.

Norman, P. J. (2011). Planning for what kind of teaching? Supporting coorporating teachers as teachers of planning. Teacher Education Quarterly, 38(3), 49-68.

Ozturk, I.H. (2012). Teacher's role and authonomy in instructional planning: The case of secondary school history teachers with regard to the preparation and implementation of annual instructional plans. Educational Sciences: Theory and Practice, 12(1), 344-349.

Sanchez, G., \& Valcárcel, V.M. (1999). Science teachers' views and practices in planning for teaching. Journal of Research in Science Teaching, 36(4), 493-513. https://doi.org/10.1002/(SICI)1098-2736(199904)36:4<493::AID-TEA6>3.0.CO;2-P

Sardo-Brown, D. (1990). Experienced teachers’ planning practices: A U.S. survey. Journal of Education for Teaching, 16, 57-71. https://doi.org/10.1080/0260747900160104

Skott, C.K., \& Kass, T. (2015).Matematiklæreres planlægningspraksis og målstyret undervisning. MONA, 4, 7-24.

Sivesind, K., Akker, J. v. d., \& Rosenmund, M. (2012). The European curriculum: restructuring and renewal. European Educational Research Journal, 11, 320-327. https://doi.org/10.2304/eerj.2012.11.3.320

Stúkat, S. (1998). Lärares planering under och efter utbildningen. Gøteborg: Acta Universitatis Gothengurgensis.

Sullivan, P., Clarke, D. J., Clarke, D. M., Farrell, L., \& Gerrard, J. (2012). Processes and priorities in planning mathematics teaching. Mathematics Education Research Journal, 24, 457-480.

Superfine, A. C. (2008). Planning for mathematics instruction: A model of experienced teachers' planning processes in the context of a reform mathematics curriculum. Mathematics Educator, 18(2), 11-22.

ten Have, P. (2004). Understanding qualitative research and ethnomethodology. London: Sage. 
Tyler, R.W. (1950). Basic principles of curriculum and instruction. Chicago: University of Chicago Press.

Undervisningsministeriet (2009). Fælles Mål 2009 - Matematik: Faghæfte 12. København: Undervisningsministeriets håndbogsserie nr. 14.

Undervisningsministeriet (2014). Læringsmålstyret undervisning i folkeskolen. Vejledning. Retrieved from www.emu.dk (27/3/2017).

Undervisningsministeriet (2016a). Matematik. Fagformål for faget matematik. Retrieved from www.emu.dk $(27 / 3 / 2017)$.

Undervisningsministeriet (2016b). Dansk. Fagformål for faget dansk. Retrieved from www.emu.dk (27/3/2017).

Warren, L. L. (2000). Teacher planning: A literature review. Educational Research Quarterly, 24(2), 37-42.

Yin, R.K. (2003). Case study research: Design and methods. London: Sage.

Yinger, R. (1980). A study of teacher planning. Elementary School Journal, 80, 197-227. https://doi.org/10.1086/461181 